158 肝細胞を標的とした遺伝子運搬担体の開発

17:16-17:56

核：骨

159 多発性骨髄腫の骨シンチグラフィ-長幹骨端の異常集積-

160P骨シンチグラムにおける骨外異所性集積の検討
京都大 核 佐賀恒夫

座長：福永仁夫

慈恵医大附属柏 放 内山眞幸

国立別府 放 大塚 誠

るか?

愛媛大 放 菅原敬文 群馬大 核医 加藤克哉 福井医大 放 土田龍郎
162 急性の良性骨折と転移性骨折の早期鑑別における, FDG-PETの有用性

163 標準入力関数を用いたF-18 fluorideによる非侵襲的骨代謝量測定の可能性

\title{
JRS 第9会場
}

\section{9:00-9:48 治：前立腺1(小線源)}

164 前立腺癌組織内照射治療後のPSA評価とその問題点

165 前立腺癌に対する高線量率小線源治療

166 経直腸エコー(TRUS) ガイド下穿刺による前立腺癌の低線量率小線源治 技術的改善方法

167 前立腺癌に対する外照射併用高線量率組織内照射法の初期経験

168 前立腺癌に対する高線量率組織内照射

169 高齢者の前立腺癌 (T2, T3) に対する外照射と小線源併用療法について

9:48-10:36

治：前立腺2

170 前立腺癌術後 PSA failure に対する放射線治療の初期経験

171 前立腺癌biochemical failure 症例の放射線治療

172 正常前立腺への放射線照射が血清前立腺特異抗原に与える影響

173 前立腺癌病期B-Cに対するホルモン・放射線外部照射併用療法

174 前立腺癌に対する炭素イオン線の第1/2相臨床試験

175 前立腺陽子線照射時の直腸内バルーンの使用によるorgan motionの抑制と直腸線量の低減効果 兵庫県立粒子線医療セ 放 香川一史

15:00-15:40

治：前立腺3, 膀胱

176 前立腺癌の局所放射線治療成績

177 前立腺癌に対する放射線治療成績

178 前立腺癌症例に対する根治的放射線治療成績の検討

179 前立腺癌に対する放射線治療

180 浸潤性膀胱癌に対する動注化学療法併用放射線治療による膀胱温存の可能性と治療成績について

長崎市民病院 放 南 和徳

15:40-16:20

治 : 前立腺4

181巴動き回る前立腺-前立腺癌の放射線治療時のset-up error とinternal movementについての検討

山梨医大 放 永田幹紀

182 前立腺癌に対する放射線治療における前立腺位置変化の評価

183 前立腺癌に対するIMRT の臨床初期経験

184D前立腺癌に対するIMRTの臨床応用：DVHからみた setup errorの影響

国立がんセ東 放 二瓶圭二

京大 放 根来慶春

千葉がんセ 放治 幡野和男

185 前立腺癌に対する強度変調放射線治療にむけた骨盤部固定具による患者位置再現精度の検証

京大 放 高山賢二

16:20-16:52

治：リンパ腫 1

186 中枢神経原発リンパ腫に対して全脳照射は必要か?一非全脳照射例の再発形式の分析一

座長 : 早㴊尚文

187 眼窝原発非ホジキンリンパ腫の治療成績

188 眼窝内リンパ系腫瘍の放射線治療成績と副作用

189 Stage I/II Non-Hodgkin Lymphoma における予後因子としての腫瘍径の重要性

$\begin{array}{rrl}\text { 京大 } & \text { 放 } & \text { 芝本雄太 } \\ \text { 信州大 } & \text { 放 } & \text { 西川 敦 } \\ \text { 帝京大市原 } & \text { 放 } & \text { 上野直之 }\end{array}$

信州大 放 小岩井慶一郎
治：リンパ腫2，軟部

190 新WHO分類に基づく非ホジキンリンパ腫の臨床病理学的検討

191 乳腺原発悪性リンパ腫に対する放射線化学療法の治療経験

192 MALTリンパ腫(胃以外)に対する放射線治療経験
座長 : 笹井啓資

群馬県立がんセンタ一放射線科 樋口啓子 癌研 放 加藤大基 慈恵医大 放 福田一郎 